\title{
Research
}

\section{Exploring Social Capital in Chile's Coastal Benthic Comanagement System Using a Network Approach}

\author{
$\underline{\text { Andrés Marín }}^{1,2,3}$. Stefan Gelcich $^{1,4}$, Juan C. Castilla $^{1,4}$, and Fikret Berkes $^{3}$
}

\begin{abstract}
Comanagement success relies on the proper administration of resources and on the capacity of users to establish and maintain positive social relationships with multiple actors. We assessed multifunctional relationships of small-scale artisanal fisher organizations engaged in a coastal benthic resources comanagement system in Chile to explore bridging and linking social capital, using an egocentric network approach. The formal leaders of 38 small-scale fisher organizations were surveyed to investigate (1) similarities and differences in social capital among fisher organizations and regions, and (2) possible effects of social capital levels on comanagement performance. Results show that the best performing fisher organizations are those with higher levels of linking and bridging social capital. Positive and strong correlations exist between linking social capital levels and comanagement performance variables. Importantly, fisher organizations considered to manage resources successfully consistently presented high levels of linking social capital, irrespective of variability in bridging social capital. Using egocentric networks allows understanding actors' differences in the comanagement social structure, thus providing critical insights for improving comanagement systems.
\end{abstract}

Key Words: artisanal fisheries; benthic resources; bridging social capital; Chile; coastal fisheries; comanagement; egocentric; human dimensions; linking social capital; territorial use rights

\section{INTRODUCTION}

The use of the social capital concept has increasingly penetrated the field of natural resource management. Social capital has been defined as a blend of networks, trust, norms, and reciprocity among members of the society, with different emphases to these components given by different authors (Bourdieu 1986, Coleman 1988, Putnam 2000). Despite the diversity of definitions, the core promise of social capital remains unquestionably appealing: the investment of individuals and collectives in social relationships can be expected to have paybacks in other forms of capitals, with the consequent enhancement of opportunities and capacities to achieve their goals (Portes 1998). Accordingly, higher levels of social connectivity and social capital are associated with improved social performance and natural resource management outcomes and processes (Pretty and Ward 2001, Ballet et al. 2007).

Comanagement refers to the joint management of common pool resources involving multiple actors from different areas of the society (Borrini-Feyerabend et al. 2004, Berkes 2007, 2009). Key functions of comanagement are the exchange of resources and the establishment of linkages among organizational groups at different hierarchical levels (Carlsson and Berkes 2005). Thus, the manner in which the relationships among parties are structured and the extent to which valuable resources are mobilized can be expected to affect both the overall governance of comanagement and individual user groups' socioeconomic performance (Carlsson and Sandström
2008). In this vein, a growing literature using a social network perspective has explored which and how network structural patterns, such as centrality, density, and heterogeneity, would enhance social capital and support sustainable comanagement governance systems (Bodin et al. 2006, Bodin and Crona 2008, 2009). The underlying approach of these projects has been termed sociometric, namely the study of the relational patterns of whole networks and the positions therein (Lakon et al. 2008). A complementary approach to social capital, namely the egocentric approach, focuses on the network defined from the vantage point of a single actor or "ego" for some role relationship, and on the effects on his/her actions (Van der Gaag and Webber 2008). This approach allows for a focus on the performance of individual cases within comanagement systems when network boundaries are unclear (Lakon et al. 2008). Our aim is to assess to what extent social capital, measured by means of egocentric networks, make a difference in the performance of comanagement.

In this study we apply the egocentric network approach to social capital to investigate fisher organizations participating in Chilean comanagement, namely the Management and Exploitation Areas for Benthic Resources (MEABR) system (Castilla 1994, Castilla et al. 1998). Various factors have been assessed as possible determinants of MEABRs success, including economic and technical (SUBPESCA 2004), biophysical (Thiel et al. 2007), and organizational and leadership aspects (Schumann 2007). However, this is the first time the role of social capital in the performance of the

\footnotetext{
${ }^{1}$ Centro de Estudios Avanzados en Ecología y Biodiversidad and Departamento de Ecología, Pontificia Universidad Católica de Chile, ${ }^{2}$ Stockholm Resilience Centre, Stockholm University, Sweden, ${ }^{3}$ Natural Resources Institute, University of Manitoba, Canada, ${ }^{4}$ Laboratorio Internacional en Cambio Global (CSIC-PUC), Esporles, Spain
} 
Fig. 1. Conceptual model. The research aims at assessing the relationship between linking and bridging social capital and comanagement performance of fisher organizations participating in the Chilean coastal MEABR system. Question marks stand for our hypothesis. MEABR = Management and Exploitation Areas for Benthic Resources.

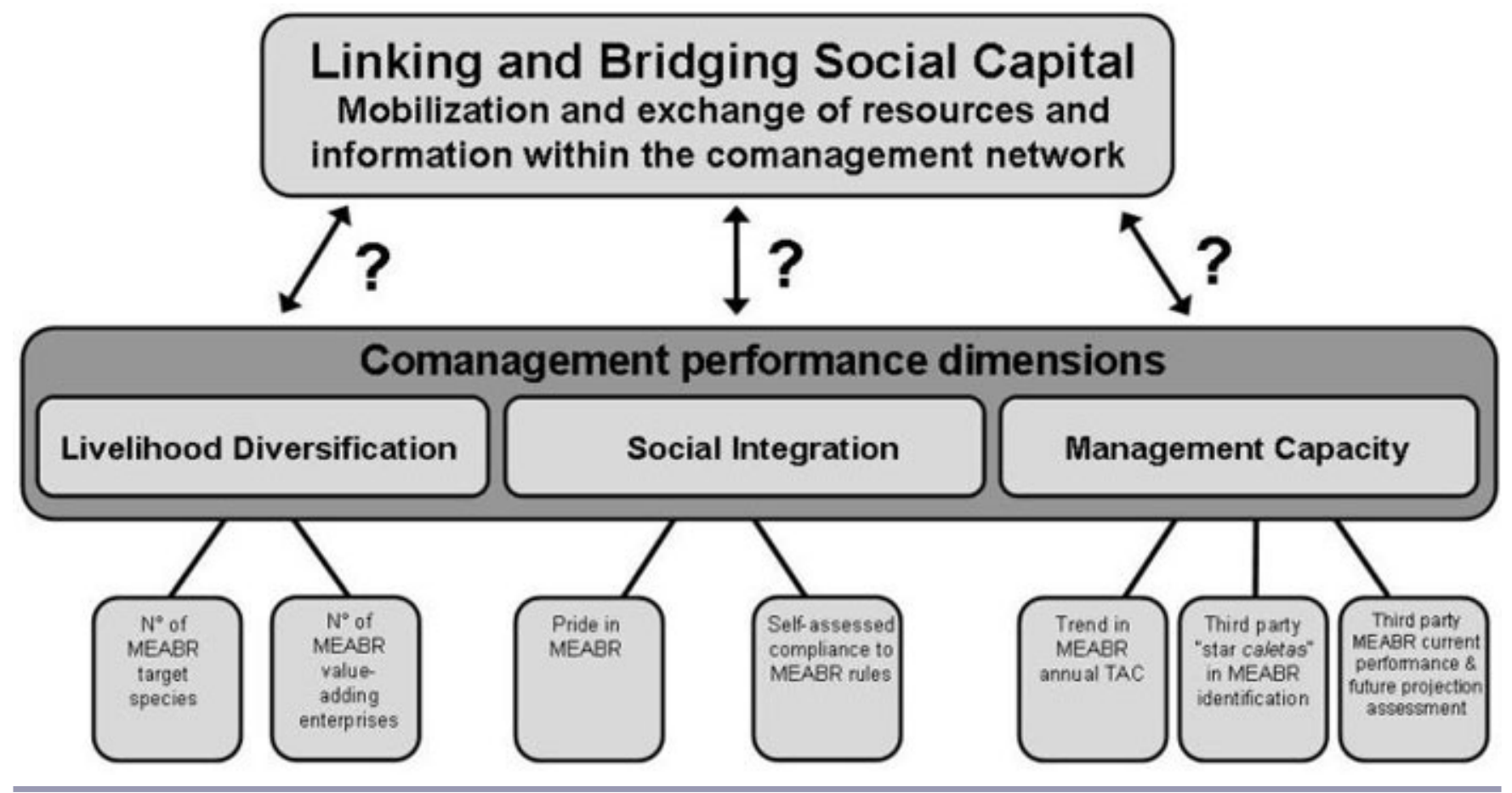

MEABR comanagement system is systematically measured. In particular, we address relationships among groups at the same hierarchical level, termed bridging social capital, and linkages of organizations vertically with actors and institutions beyond the community level, termed linking social capital (see Woolcock 2001), associated to comanagement performance dimensions, namely livelihood diversification, social integration, and management capacity (Fig. 1).

We present theoretical and operational definitions of social capital and the egocentric network approach and background to the MEABR system and describe the research area and methods. The results focus on the relation between social capital at the organizational level and the performance of comanagement cases. The discussion underlines lessons and policy implications.

\section{Social capital, networks, and the egocentric approach}

The origins of the contemporary social capital concept can be traced back to Bourdieu (1979) and Coleman (1988), whose attempt was to explore the role of social relationships in the creation of other forms of capital, such as human, economic, and cultural capitals. The concept rapidly evolved, broadening its definition to include other components such as reciprocity, social integration, rule of law, norms, and trust (Borgatti et al. 1998, Portes 1998). Among the multiple strands of theoretical and empirical development, social capital research has found solid methodological grounds in the social network analysis tradition (Borgatti et al. 1998, Lin 1999, Lakon et al. 2008). The network approach to social capital refers to valuable resources that are embedded in the social structure and differentially accessed and/or mobilized in purposive actions by social actors (Borgatti et al. 1998, Lin 2001). Accordingly, defining components of social capital are the resources embedded in the social structure and the social relationships that channel them among actors (Portes 1998). Connectedness of actors in networks and groups provides potential access to key resources, such as information, knowledge, influence, and funding, affecting their opportunities.

Network-based understanding of social capital comprises the sociometric and egocentric approaches. The former refers to the study of structural properties of whole networks with clearly defined boundaries, and requires data to be collected from all its members. The latter highlights the value of individual actors' social relationships, focusing on the network defined from the vantage point of a single actor or "ego" for some role relationship (Lin 1999, 2001). This approach relies on information about the portion of a network in the immediate locality of a given node or set of nodes (Marsden 2002). Whereas sociometric social capital resembles Coleman's (1988) emphasis on network closure, e.g., density and 
cohesion, as favoring the rise of social capital within a given system with effects on the collective, the egocentric approach echoes Lin (1999) and others who associate social capital with bridging gaps or structural holes between otherwise disconnected (sub)systems (Adler and Kwon 2002). These external connections potentially provide "egos" with resources they do not possess and they depend on for improved performance. Distribution of social capital among actors is naturally unequal. "Obviously, not all individuals or social groups uniformly acquire social capital or receive expected returns from their social capital" (Lin 2000:786). Understanding the uneven distribution of social capital over the population, assessing its correlation with goal attainment, and determining which configuration, part, or resources domain of social capital can be more effective in a certain context represent key questions of ego-centered research (Van der Gaag and Webber 2008) also guiding this study. Using egocentric networks allows for understanding actors' differences in the social structure, and for making predictions about how these locations constrain or enable their behavior (Hanneman and Riddle 2005).

The egocentric approach is complemented in this study with the three-type social capital framework (Woolcock 2001): bonding, bridging, and linking social capitals; we concentrate on the last two types. Bonding social capital is formed by strong kinship, ethnicity, or neighborhood ties among relatively homogeneous individuals within the same community or group. This type is equivalent to the closure argument explained above and, therefore, excluded from this research. Bridging social capital consists of more distant, weaker, and more diverse ties, and takes place between members from distinct communities and groups at the same level (Woolcock 2001, Woolcock and Sweetser 2002). Bridging social capital represents a relevant resource in making the mobilization of opportunities possible. Relying on bridging linkages as social lubricant, people and groups manage to achieve their goals and to "go ahead" together (Putnam 2000). These linkages constitute horizontal networks of civic engagement that help participants to act collectively to produce impacts on community productivity and wellbeing.

Linking social capital refers to relations of respect and trust between local groups and actors in explicit, formal, or institutionalized higher levels of political, economic, or social hierarchy (Szreter \& Woolcock, 2004). It includes the ability of local communities and groups to engage with the state and external agencies either to influence their policies or to access useful resources and information (Woolcock 2001, Woolcock and Sweetser 2002). Linking social capital is mostly about power negotiations and economic exchange networks. Linking relationships have also been referred to as cross-scale interactions or linkages (Berkes 2006, Cash et al. 2006). The implications of these cross-scale linkages for local actors are multiple. Bodin and Crona (2009) depict them as negotiated outcomes of power relations that reproduce the hierarchies of institutions and actors. Newman and Dale (2005) argue that such vertical interplay, depending on its structure, may change the nature of the bargain and power relations between stakeholders and access to people in power. The notion of linking social capital captures, but is not reduced to, the important role of government institutions and policies in local development.

Most of the literature and research on social capital has focused on the positive outcomes of social relationships (Bourdieu 1986), but there is also a negative side (Portes and Landolt 2000, Woolcock and Narayan 2000). Networks do not only mobilize social goods but also enable disorganizing or undesirable activities (Woolcock and Narayan 2000). Social relationships can be negative, for instance with opponents who try to hinder one's goal achievement (Moerbeek and Need 2003). Also, too many linkages with diverse actors may imply having too many counterparts to serve (Bodin and Crona 2009) and independence may be reduced. However, the integration of the positive and negative sides of social capital and networking in empirical research is underdeveloped (Van der Gaag and Webber 2008), especially in a comanagement setting. This study considers one actor's social capital as a net balance between his/her positive and negative relationships for the first time.

\section{The Chilean benthic comanagement system for the small-scale fishery sector}

The MEABR comanagement system was established by law in 1991 in response to a benthic resources overexploitation crisis with highly negative social and economic consequences (Castilla 1994, Gelcich et al. 2010). The policy was formally implemented nation-wide in 1997 (Castilla et al. 1998) after a trial period including several pilot cases. The MEABR regime calls organized fishers to apply for exclusive exploitation rights over a portion of coastal seabed and the resources within. Drawing on a base-line assessment and a management plan prepared by hired fishery consultants, fisher organizations sign a four-year renewable agreement with the state and are vested with territorial user rights. Total allowable catches (TAC), ranging from 15 to $25 \%$ of the total stock, are established annually for specific target species within each area.

To benefit from public programs, such as the MEABR system, fishers have to establish and enlist unions or cooperatives. Currently more than 620 small-scale fisher organizations exist, but in practice, only $50 \%$ of them apply for MEABRs. The benthic fishery is associated with the job of hookah divers operating from 5-8 m open-hull boats equipped with outboard engines (Castilla 2010). The main target species exploited under the MEABR system include 'loco' (Concholepas concholepas), 'lapas' (Fissurella spp.), 'erizo' (Loxechinus 
albus), sea squirt (Pyura chilensis), clams (Mesodesma donacium, Venus antiqua), and various species of seaweed (for example, Lessonia trabeculata; Gelcich et al. 2006, 2010).

The functioning of MEABRs is permanently supervised by the fishery agencies Subsecretaría de Pesca (SUBPESCA; the Undersecretary of Fisheries) and Servicio Nacional de Pesca (SERNAPESCA; the National Fishery Service), mainly by means of revising management plans and follow-up reports, including TACs, and enforcing the policy locally. Authorities also control the MEABR procedures and the payment of a territorial fee (San Martín et al. 2010). Besides these legal duties, fishers make harvesting decisions, including the definition of the proportion of TAC to be gathered and the timing of harvests (within the officially established harvest season), the price they will accept for resources, the number of buyers to whom they sell, and distribution criteria of benefits among members (Gelcich et al. 2007). Other decisions concern members' MEABR entry/exit rules, penalties to infringers, and the implementation of surveillance mechanisms.

The MEABR system is dynamic in terms of active users and the associated MEABRs. According to SUBPESCA (2010), new areas are being permanently proposed to the state by fisher organizations, a reflection of a growing demand. A number of MEABRs become formally inactive every year because of the noncompliance of legal requirements. Other MEABRs are voluntarily returned to the authority, presumably because of unsatisfactory results. Certainly, the good functioning and performance of particular MEABRs cannot be taken for granted and comanagement capacity of fisher organizations is permanently put to the test. Various factors have been assessed as possible determinants of MEABRs success (SUBPESCA 2004, Schumann 2007, Thiel et al. 2007). However, few studies have referred to the role and importance of social capital in the performance of the MEABR comanagement system (Gelcich et al. 2006, Schumann 2010), while none has attempted to empirically measure it.

\section{METHODS}

\section{Study area}

Our research covers two administrative regions in centralsouthern Chile, Valparaíso and Bio-Bio, with a sample of 16 and 22 fisher organizations, respectively (Appendix 1). The purposive sample (time-effective criteria) represents 64 and $50 \%$ of the organizations involved in 2008 in the MEABR system in those regions, accounting for approximately 2250 users. We trust the high coverage to compensate for the biases of nonprobability sampling.

Bio-Bio is among the three most important regions in Chile in terms of small-scale fisheries in general, and of benthic resources catch in particular, whereas Valparaíso is relevant because it hosts the headquarters of SUBPESCA and concentrates decision making. In addition, fishing villages and coves (caletas in Spanish; see Castilla et al. 1998) are mostly rural in Bio-Bio and urban in Valparaíso. Differences in fishing intensity, proximity to central authorities, and relative isolation of resource users define two distinct study settings and justify the selection for the purpose of empirical comparison.

\section{Research design}

The research employed a two-mode egocentric network approach to the study of social capital. Focal actors or egos, representing the first mode, were fisher organizations in the MEABR system. Organizations were regarded as single entities that have relationships with other institutions (Borgatti et al. 1998). The elected president/leader was the person in charge of channeling these relationships on behalf of the group. Hence, he/she has been regarded as the "gatekeeper" with respect to comanagement affairs and a valid informant for similar studies (Marín and Berkes 2010). The president of each of the 38 cases studied was interviewed.

Using semistructured questionnaires, presidents/leaders were asked about their relationships with 28 comanagement counterparts or "alters" included in an open-ended roster, namely the actors in the second mode (Appendix 2). The list of actors was generated from exploratory interviews, the literature, and policy documents, and included government institutions, private organizations, and other fisher organizations and associations. In the questionnaire, comanagement counterparts were expressed in generic terms, e.g., universities, the municipality, and fisher federations, rather than individualized entities, e.g., Universidad de Concepción, Municipality of Quintero, and FEREPA Bio-Bio, to ensure meaningfulness in different and distant administrative and geographical settings. The reference to social roles to which egos have connections, provide not only a picture of the individual egocentric networks but also a more general report of the networks of social positions in which egos are embedded (Hanneman and Riddle 2005).

The role relationship studied was comanagement, defined as the linkages established by the organizations for MEABR development. The specific question was: How would you define the following institutions and organizations' participation in the development of your MEABRs? (the exact term used in Spanish was "desarrollo del Area de Manejo"). This allowed the inclusion of the diverse counterparts, playing different functions in and providing multiple resources for comanagement (Appendix 2). Interviewees were first asked to characterize comanagement relationship valence with each counterpart as either "facilitating," "hindering," or "nonexistent" for comanagement. Then, respondents were asked to express relationship strength in terms of level of "trustworthiness" with respect to each actor involved, using Likert type scales.

\section{Social capital indices}

Composite indices allow summarizing data on complementary dimensions of a phenomenon and have been used for social 
capital measurements (Krishna and Uphoff 1999, Putnam 2001). Here, two indices were developed to integrate valence, strength, and other qualities of egocentric comanagement networks and to express linking and bridging social capital levels. Borgatti and coauthors (1998) proposed different network metrics to account for social capital. Drawing on their work, our indices consist of equations based on the degree centrality measurement. The degree reflects the relative prominence of focal points within a network, based on the level of connecting activity (Faust 1997, Hanneman and Riddle 2005). For two-mode networks, degree centrality refers to each actor's total number of linkages, expressed as a proportion of the maximum number of possible linkages (Borgatti and Everett 1997, Faust 1997). The developed indices represent a weighted degree-based centrality measurement and run from 0 to 1 to ease interpretation.

The Linking Social Capital Index (LSCI) captures the set of connections of each organization with actors at other scales, specifically actors in the second mode, and is composed of three elements (see equation below): (1) Net facilitating degree equals facilitating degree $(F d)$ minus hindering degree $(H d)$; (2) Net trustworthiness degree equals trustworthy degree $(T d)$ minus untrustworthy degree $(U d)$; (3) Heterogeneity factor $(H f)$ or the variety of alters with respect to relevant dimensions (Borgatti et al. 1998), defined here as the proportion of functional groups, e.g., power-sharing and enforcement; monitoring, research and development; and marketing, identified by Marín and Berkes (2010) with which the organization has facilitating and trustworthy relationships (Appendix 2). Heterogeneity of actors in a network can be a key feature of well-performing comanagement networks because of the variety of resources they may provide (Carlsson and Sandström 2008). The LSCI score for each organization is computed as the simple mean of the three components.

$$
L S C I=\frac{(F d-H d)+(T d-U d)+(H f)}{3}
$$

The Bridging Social Capital Index (BSCI) captures horizontal linkages between fisher organizations at the same level, and is calculated as the simple mean of three elements (see equation below): (1) and (2) as described above for the LSCI but with respect to horizontal relationships with other near and far caletas, presented as two distinct categories; and (3) a complementary factor $(C f)$ using other questionnaire items referring to specific inter-caleta positive linkages, also expressed as a proportion. These include whether horizontal relationships are considered highly important to the development of comanagement, a source of learning for resource management, or if there is any kind of alliance with respect to MEABR operations. Bridging ties have been considered important for the activation of collective action in collaborative contexts (Krishna 2002, Carlsson and Sandström 2008). It must be noted that observed horizontal linkages led to a relationship data matrix with cases clustered at two extremes. The complementary factor was included to obtain a more diversified distribution of data and to better account for bridging social capital.

$$
B S C I=\frac{(F d-H d)+(T d-U d)+(C f)}{3}
$$

\section{Comanagement performance}

Three dimensions of comanagement performance group the variables used to explore the role of social capital in the MEABR system (Fig. 1), namely:

- Livelihood diversification: Good performance of comanagement is associated with it representing a complimentary source of income, and not a complete economic solution for divers and fishers (Gelcich et al. 2005). Horizontally and vertically diversified livelihoods express enhanced users' adaptive capacities to environmental and market changes. Here, indicators of livelihood diversification of fisher organizations are, first, the variety of resources formally managed in and targeted from MEABRs. The number of species included in management plans can vary depending both on biophysical, e.g., natural productivity, and/or management variables, e.g., knowledge, gear, and technology. Second, livelihood performance is measured as the development of clustered value-adding activities such as tourism and commercialization that can increase revenues as a complement of MEABR.

- Social integration: The MEABR policy was established to promote the formalization, regulation, and inclusion of the small-scale artisanal sector into the emergent market-based economy (Bernal et al. 1999). In this context, good comanagement performance in Chile can be associated with users' self-regulation and sense of social recognition (Castilla and Fernandez 1998, Gelcich et al. 2010). Indicators of social integration used in this research are, (1) the perceived overall level of MEABR rule compliance of members, e.g., the prohibition to poach, when and how much to extract, and the obligation to participate in stock assessments, and (2) the level of members' pride in MEABRs, as declared by fisher leaders.

- Management capacity: The MEABR system design was driven by the overexploitation of benthic resources observed in the late 1980s and early 1990s (Castilla 1994). The policy devolved power and delegated management attributions to local users to ensure stock recovery and ecological sustainability (San Martín et al. 2010). Here, good comanagement performance is regarded as a combination of capacities and associated biological results, and measured as: (1) tendency in 
Table 1. Comanagement performance dimensions, variables, and indicators for the Management and Exploitation Areas for Benthic Resources (MEABR) system.

\begin{tabular}{|c|c|c|c|}
\hline $\begin{array}{l}\text { Dimension } \\
\text { Variables } \\
\end{array}$ & Survey question / source & Scale & $\begin{array}{l}\text { Justification of variable in the } \\
\text { Chilean context }\end{array}$ \\
\hline \multicolumn{4}{|l|}{ Livelihood Diversification } \\
\hline No. of MEABR target species & $\begin{array}{l}\text { How many species are included } \\
\text { in your MEABR Management } \\
\text { Plan? Which ones? }\end{array}$ & Numeral & $\begin{array}{l}\text { More species targeted as part of } \\
\text { Management Plans = more } \\
\text { diversified exploitation } \\
\text { opportunities and more stable } \\
\text { livelihood throughout the year }\end{array}$ \\
\hline No. of value-adding enterprises & $\begin{array}{l}\text { Besides the MEABR, do you } \\
\text { perform other economic } \\
\text { activities as a fisher } \\
\text { organization? Which ones? }\end{array}$ & Numeral & $\begin{array}{l}\text { Diversified economic activities }= \\
\text { increased revenues as } \\
\text { complements to sustainable } \\
\text { MEABR }\end{array}$ \\
\hline \multicolumn{4}{|l|}{ Social integration } \\
\hline Pride in MEABR & $\begin{array}{l}\text { In our organization we are proud } \\
\text { of our MEABR }\end{array}$ & $\begin{array}{l}4=\text { Highly agree to } \\
1=\text { Highly disagree }\end{array}$ & $\begin{array}{l}\text { More pride with MEABR = } \\
\text { higher recognition of fishers' } \\
\text { stewardship role in benthic } \\
\text { resources sustainability }\end{array}$ \\
\hline $\begin{array}{l}\text { Self-assessed compliance to } \\
\text { MEABR rules }\end{array}$ & $\begin{array}{l}\text { Our union members observe the } \\
\text { management agreement to the } \\
\text { letter }\end{array}$ & $\begin{array}{l}4=\text { Highly agree to } \\
1=\text { Highly disagree }\end{array}$ & $\begin{array}{l}\text { More compliance = reduced } \\
\text { poaching and better self- } \\
\text { governance }\end{array}$ \\
\hline \multicolumn{4}{|l|}{ Management capacity } \\
\hline $\begin{array}{l}\text { Trend in official MEABR annual } \\
\text { TACs }\end{array}$ & SUBPESCA statistics & $\begin{array}{c}1=\text { Increased } \\
-1=\text { Decreased } \\
0=\text { No significant trend }\end{array}$ & $\begin{array}{l}\text { Biologically assessed MEABR } \\
\text { TACs maintained or increased = } \\
\text { sustained resources stocks }\end{array}$ \\
\hline $\begin{array}{l}\text { Third party assessed "star } \\
\text { caletas" }\end{array}$ & $\begin{array}{l}\text { MEABRs considered successful/ } \\
\text { model cases of comanagement in } \\
\text { each region }\end{array}$ & $\begin{array}{c}1=\text { Star caleta } \\
0=\text { Other caletas }\end{array}$ & $\begin{array}{l}\text { "Star caletas" = overall most } \\
\text { successful MEABR cases }\end{array}$ \\
\hline $\begin{array}{l}\text { Third party assessed current } \\
\text { performance of MEABR }\end{array}$ & $\begin{array}{l}\text { Which of these words describes } \\
\text { better the overall performance of } \\
\text { the following fisher } \\
\text { organizations' MEABR? }\end{array}$ & $\begin{array}{c}5=\text { Success } \\
4=\text { Stability } \\
3=\text { Improvement } \\
2=\text { Stagnation } \\
1=\text { Failure }\end{array}$ & $\begin{array}{l}\text { Better current results }=\text { better } \\
\text { perceived management capacities }\end{array}$ \\
\hline $\begin{array}{l}\text { Third party assessed future } \\
\text { projection of MEABR }\end{array}$ & $\begin{array}{l}\text { Assign a score to each } \\
\text { organization reflecting its future } \\
\text { projections with respect to their } \\
\text { MEABR performance? }\end{array}$ & $\begin{array}{c}5=\text { Good performance to } \\
1=\text { Bad performance }\end{array}$ & $\begin{array}{l}\text { Better future projections = better } \\
\text { perceived long-term management } \\
\text { capacities }\end{array}$ \\
\hline
\end{tabular}

resource stocks within MEABRs, using annual TACs as proxy indicators, based on official data, and calculated using regressions; (2) third party spontaneous identification, during exploratory in-depth interviews, of "star caletas", namely those few organizations that are commonly considered the most successful and model MEABR in their regions (see Appendix 3); (3) third party assessment of the overall current performance and future projection of each fisher organization studied. Five SERNAPESCA public managers with field experience, presumably the observers with the broadest vision of all caletas within territories, were surveyed to capture an external evaluation about the fisher organizations sampled with regards to comanagement.

Table 1 presents a detailed description of the indicators outlined above, their source, type of scale used, and the rationale on how these attributes are considered to be associated with comanagement performance.

Statistical analyses were performed using SPSS and SigmaStat software, and include t-test to explore differences in social capital levels between regions, one-way ANOVA with a posteriori Tukey test to establish differences among social capital groups, and Kolmogorov-Smirnov tests to compare social capital groups in both regions. We also used Spearman correlations to assess significant relations between social capital and performance variables. Finally, ANOVAs with Tukey analysis or Kruskal-Wallis with Dunn's pairwise comparisons were applied to contrast characteristics among different subsets of cases, depending on the normality of the data set. 


\section{RESULTS}

\section{Linking and bridging social capital distribution}

Results show a highly uneven distribution of linking and bridging social capital levels among fisher organizations studied (see observed scores and SE in Table 2). Both linking (LSCI) and bridging index (BSCI) scores range from above 0.6 to negative figures. Negative social capital scores represent situations in which overall hindering and untrustworthy relationships of certain organizations with comanagement counterparts surpass those defined by facilitation and trust. Even though linking and bridging indices are conceptually not comparable; observed mean values show that LSCI (0.401) is closer than BSCI (0.136) to the theoretical maximum.

Table 2. Linking and bridging social capital levels.

\begin{tabular}{|c|c|c|c|c|c|}
\hline Indices & $\begin{array}{c}\text { Maximum } \\
\text { observed } \\
\text { scores }\end{array}$ & $\begin{array}{c}\text { Minimum } \\
\text { observed } \\
\text { scores }\end{array}$ & Mean & Median & SE \\
\hline $\begin{array}{l}\text { Linking } \\
\text { social } \\
\text { capital }^{\dagger}\end{array}$ & 0.794 & 0.179 & 0.401 & 0.432 & 0.031 \\
\hline $\begin{array}{l}\text { Bridging } \\
\text { social } \\
\text { capital }^{\ddagger}\end{array}$ & 0.611 & -0.222 & 0.136 & 0.111 & 0.039 \\
\hline
\end{tabular}

${ }^{\dagger}$ Linking social capital index is based on relationships with actors at other scales;

${ }^{*}$ Bridging social capital index is based on relationships with actors at the same scale.

The t-test analysis reported no significant differences between regions in terms of bridging $(\mathrm{P}=0.347)$ and linking $(\mathrm{P}=0.956)$ social capital distribution. Figure 2 shows similar mean values for BSCI and LSCI in the Valparaíso and Bio-Bio regions, suggesting a common pattern among small-scale fisher organizations involved in MEABRs comanagement, independent from geographical and administrative contexts.

Differences among fisher organizations were observed for linking and bridging indices simultaneously. To get a more detailed picture of the diversity in fisher organizations' access to resources embedded in the comanagement network, cases were grouped to explore commonalities of distinct types of organizations. BSC and LSC were plotted against one another and the median values were used as cutting-points for observed high and low scores within each variable. Four quadrants/ categories were defined, leading to four statistically distinct social capital groups (statistics in Fig. 3): Group 1 (G1): twelve organizations with the highest scores in the LSCI and the BSCI; Group 2 (G2): seven organizations with high scores in the LSCI but low in the BSCI; Group 3 (G3): eight organizations with low LSCI but high BRSCI scores; Group 4 (G4): eleven organizations with the lowest scores both in the LSCI and the BSCI. No significant differences were found in the distribution of cases within the four groups between Valparaíso and Bio-Bio regions (Kolmogorov-Smirnov Test, $\mathrm{P}=0.443)$.

Fig. 2. Mean linking and bridging social capital scores of fisher organizations involved in comanagement in the Valparaíso and Bio-Bio Regions. Differences between means are not statistically significant, suggesting a common pattern of linking and bridging egocentric comanagement networks of fisher organizations in both regions.

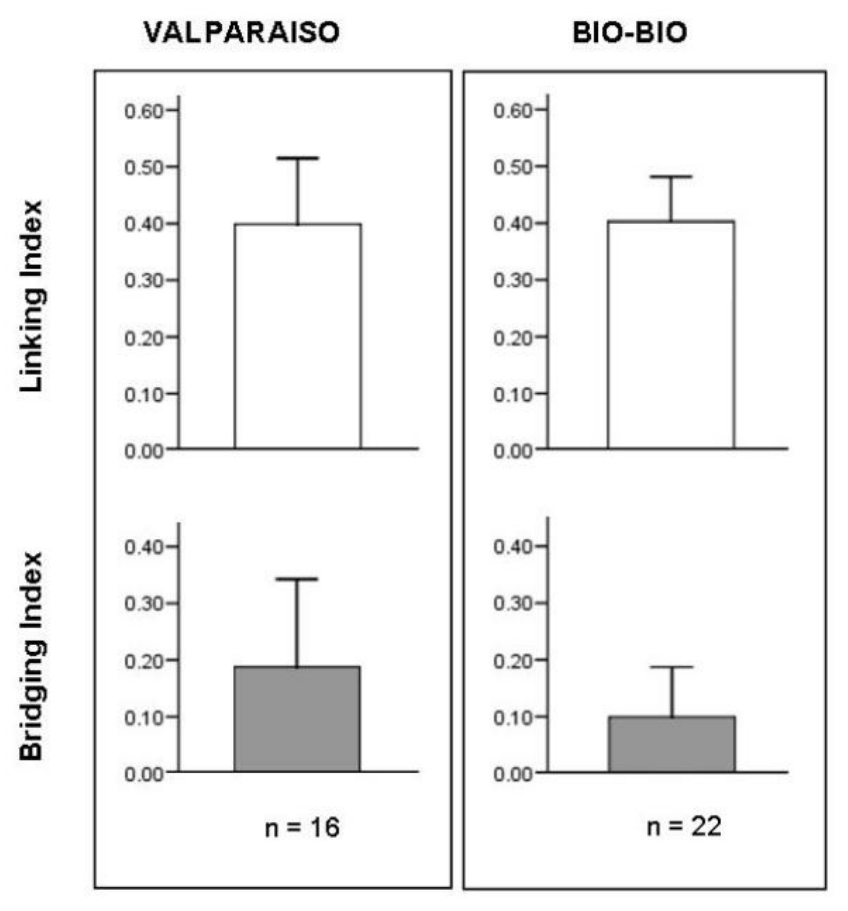

\section{Linking and bridging social capital and comanagement} performance

To examine likely effects of linking and bridging social capital on comanagement performance, two analyses were undertaken. First, correlation analysis was done between BSCI and LSCI and eight comanagement performance variables (Table 3). The LSCI is positively correlated with assessed variables in all three performance dimensions. The highest positive correlation is observed between LSCI and current performance of MEABRs $(\rho=0.575 ; \mathrm{P}<0.0001)$, followed by the number of value-adding enterprises $(\rho=0.552$; $P<$ $0.0001)$ and the "star caleta" indicator $(\rho=0.517$; P < 0.0001). In addition, low but significant correlation can be observed between LSCI and the third party assessed future projection of MEABRs $(\rho=0.451 ; P<0.05)$ and the self-assessed performance indicator of fishers' pride in the MEABRs $(\rho=$ 0.359; $\mathrm{P}<0.05$ ). By contrast, the BSCI presents low and significant positive correlations only with two indicators, 
Table 3. Spearman correlations between linking and bridging social capital indices and comanagement performance variables. MEABR = Management and Exploitation Areas for Benthic Resources.

\begin{tabular}{|c|c|c|c|c|c|}
\hline \multirow[t]{2}{*}{ Dimension } & \multirow[t]{2}{*}{ Variables } & \multicolumn{2}{|c|}{ LINKING } & \multicolumn{2}{|c|}{ BRIDGING } \\
\hline & & Spearman & $\mathrm{P}$ & Spearman & $\mathrm{P}$ \\
\hline \multirow[t]{2}{*}{ Livelihood diversification } & No. of MEABR target species & 0.27 & 0.1 & 0.117 & 0.481 \\
\hline & No. of value-adding enterprises & 0.522 & $<0.0001$ & 0.351 & 0.03 \\
\hline \multirow[t]{2}{*}{ Social integration } & Pride in MEABR & 0.359 & 0.0271 & 0.12 & 0.472 \\
\hline & $\begin{array}{l}\text { Self-assessed compliance to } \\
\text { MEABR rules }\end{array}$ & -0.171 & 0.303 & -0.236 & 0.153 \\
\hline \multirow[t]{4}{*}{ Management capacity } & Trend in official MEABR TACs & -0.084 & 0.673 & -0.0853 & 0.668 \\
\hline & $\begin{array}{l}\text { Third party assessed "star } \\
\text { caletas" }\end{array}$ & 0.517 & $<0.0001$ & -0.0563 & 0.735 \\
\hline & $\begin{array}{l}\text { Third party assessed current } \\
\text { performance of MEABR }\end{array}$ & 0.575 & $<0.0001$ & 0.124 & 0.461 \\
\hline & $\begin{array}{l}\text { Third party assessed future } \\
\text { projection of MEABR }\end{array}$ & 0.451 & 0.0046 & 0.323 & 0.0482 \\
\hline
\end{tabular}

associated with two performance dimensions, namely number of value-adding enterprises $(\rho=0.351 ; P<0.05)$ and future projections of MEABRs $(\rho=0.323 ; P=0.04)$. Noticeably, the diversity of comanaged target species, the trends in annual TACs, and the self-assessed compliance to MEABR rules showed no correlations with social capital indices.

Second, to assess likely effects of combined linking and bridging social capital, internal mean or mode values of comanagement performance variables were calculated for the social capital groups and compared using ANOVA or KruskalWallis analysis. Statistically significant differences $(\mathrm{P}<0.05)$ were observed between groups regarding three management capacity variables and one livelihood diversification variable (Table 4). The highest mean scores in this subset of variables, i.e., more positive evaluations, correspond to $\mathrm{G} 1$, whereas the lowest mean scores, i.e., less positive evaluations, are mostly concentrated in G4 (see legend in Table 4). It must be highlighted that all seven "star caletas" fell into G1 or G2. Comanagement performance variables in the social integration dimension showed no significant differences among social capital groups.

In summary, results show an uneven distribution of social capital among fisher organizations participating in the MEABR system. They also give evidence of positive correlations with variables in all three comanagement performance dimensions (Fig. 1). Linking social capital is strongly and more frequently correlated with performance variables than bridging social capital. The comparison between social capital groups reports that more and better connected organizations tend to show enhanced performance in terms of MEABR management capacity and livelihood diversification than the others.
Fig. 3. Fisher organizations' social capital groups based on linking and bridging indices. Significant differences are represented by different superscript letters and analyzed with one-way ANOVA and Dunn's posteriori tests (for Bridging Index groups $F=19.275$ and $\mathrm{P}<0.001$; for Linking Index groups $\mathrm{F}=14.338$ and $\mathrm{P}<0.001)$.

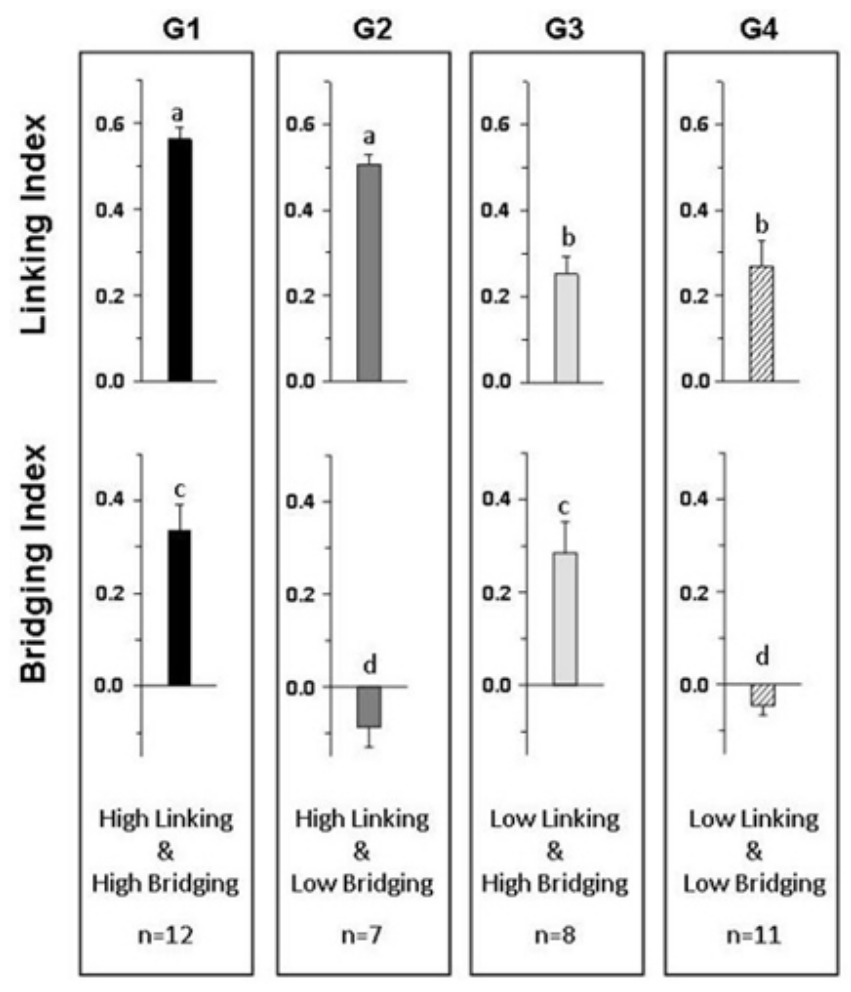


Table 4. Comanagement performance variables within social capital groups. MEABR = Management and Exploitation Areas for Benthic Resources.

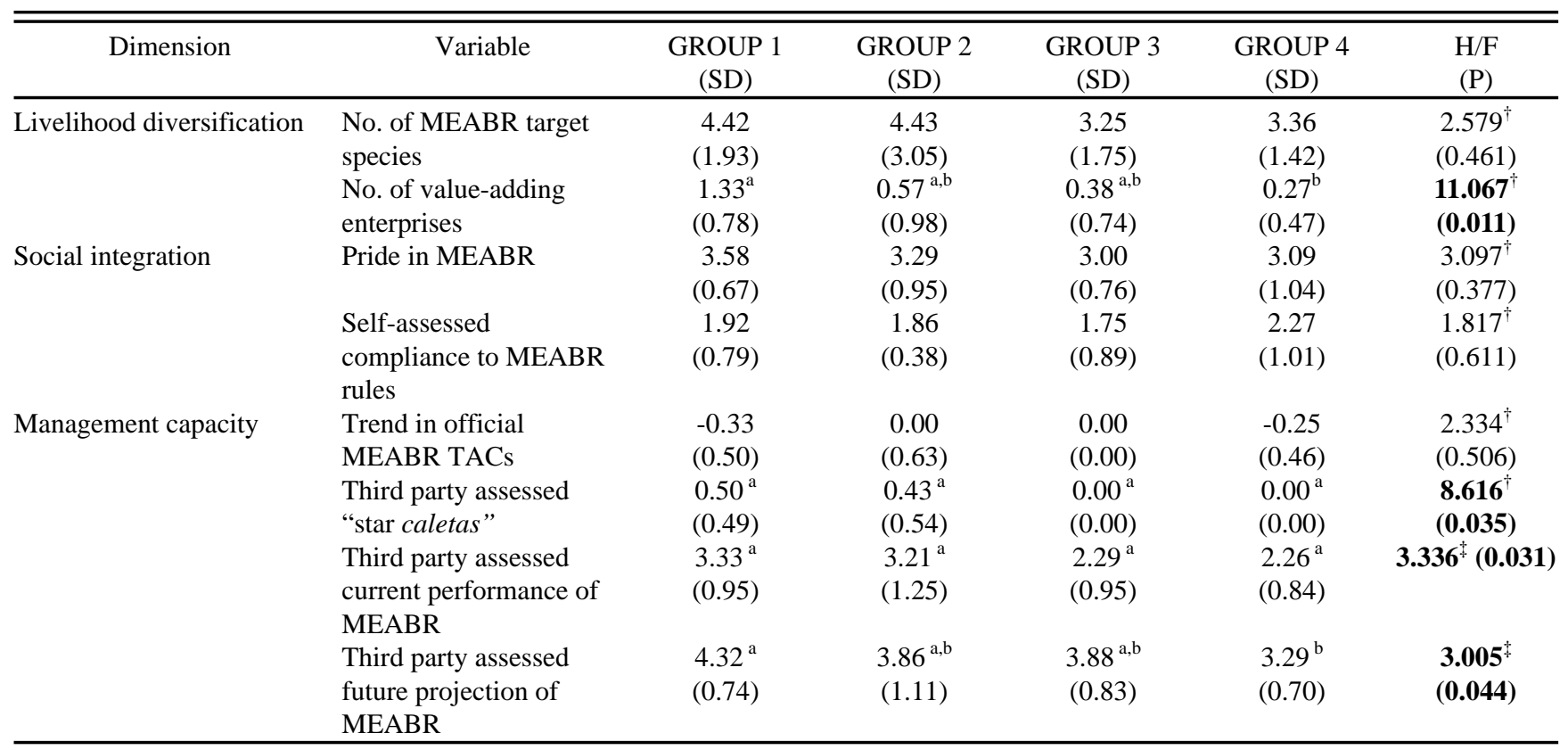

Legend: Superscript letters a and b represent significant differences between groups based on Dunn's or Tukey multiple pair wise comparisons, depending on normality of data;

'Differences among groups were analyzed with Kruskal-Wallis (statistic corresponds to $\mathrm{H}$ );

Differences among groups were analyzed using ANOVA (statistic corresponds to F).

\section{DISCUSSION}

Using meta-analysis, Gutiérrez and coauthors (2011) found social capital to be a key factor of comanagement success globally. This finding highlights the need for reliable measurements at the local level. The egocentric network approach used here makes three contributions with this respect. First, it narrows the analysis down, from the national system level to the wide array of local realities. Second, complemented with the linking and bridging social capital framework, it helps reveal different but complementary effects of vertical and horizontal relations in comanagement. Third, the construction of social capital indices allows the quantitative correlation with performance variables and the consideration of both the positive, e.g., facilitation and trust, and the negative side of social networks, e.g., hindrance and mistrust. Meaningful and reliable comanagement performance indicators and data are hard to define and costly to measure. Further development of the variables used in this study is considered necessary.

With respect to our hypothesis (Fig. 1), results show correlations between linking and bridging social capital and the performance of comanagement in Chile. The investment of fisher organizations in linking and bridging social relationships, i.e., presumably mobilizing resources and information within the comanagement network, is associated with more diversified livelihoods and better management capacities. Results also suggest that the best performing MEABRs cases are those with higher levels of linking and bridging social capital or, in other words, those with higher degree-based centrality. Recent literature on social networks and comanagement has explored the effects of different network properties on comanagement functions and processes. With respect to centralization, or the distribution of centrality within the whole network, Bodin and coauthors (2006) suggest that high levels of centrality may foster coordination but hinder learning processes. In the same vein, Carlsson and Sandström (2008) argued that high levels of centralization might improve decision making in comanagement by reducing transaction costs and promoting conflict-resolution mechanisms. Centrality has a slightly different meaning when approached from the egocentric perspective adopted in this study. Here, network centrality, as a measurement of social capital, helps explain the differential success of actors in a competitive environment (Adler and Kwon 2002). Accordingly, the egocentric approach proves useful to compare various users within the same system.

Network properties such as centrality, density, and heterogeneity have been frequently associated with trade-offs 
in comanagement, stressing the question about optimum equilibriums (Bodin et al. 2006, Carlsson and Sandström 2008, Bodin and Crona 2009). In this research, the natural question is whether there is a trade-off or perfect balance between linking and bridging social capitals. Our findings are consistent with the argument that suggests that combining the multiple dimensions of social capital can be more effective in resolving common problems and enhancing well-being (Woolcock and Sweetser 2002, Pretty 2003). It is important to highlight however, that our results put emphasis on the role of linking relations. It was LSCI and not BSCI that explained most performance differences. In addition, the best-known cases of successful comanagement or "star caletas" always had high levels of linking social capital despite the fact that they often lacked bridging social capital. This may imply that in the MEABR system, as it is currently structured, the most relevant resources and information to comanage, e.g., user rights, enforcement, expert knowledge, and funding, are sourced from external counterparts and not in peer fisher organizations. These cross-scale relationships are likely to prosper while incentives for actors at higher levels exist, but an over dependence on linking ties may risk comanagement sustainability if, for instance, market trends vary and/or government priorities and strategies toward fisheries change.

Agency and the capacity to transform social capital into concrete actions have been associated with horizontal linkages among local groups (Newman and Dale 2005). In this research, the role of bridging social capital in comanagement performance is less evident. In the Chilean case, recent research has highlighted the low capacity of fisher organizations to develop and scale-up adaptive management and to negotiate better prices with market agents (Gelcich et al. 2006). Increased poaching and conflict among users are seen as the main threats for MEABR sustainability (González et al. 2006, Gelcich et al. 2009), suggesting problems and rivalry at the horizontal level. With this respect, low bridging social capital, in concert with high bonding social capital (not measured here), have been associated with exclusion, rentseeking behavior, and lack of capacity to get ahead (OECD 2001, Grafton 2005). Our study does not allow for the establishment of direct connections with those problems. However, the positive correlation between the BSCI and perceived future projections of MEABRs, and diversified joint enterprises, suggests that comanagement performance in the face of uncertainty is associated with the capacity to maintain collaborative horizontal relationships. Potential solutions to some of the challenges faced by MEABR are possibly related to the enhancement of bridging ties and improved coordination/cooperation among fisher groups.

Chilean fishery policies, including the MEABR system, must be revised in 2012. Although a few studies have referred to the role of social capital in the Chilean comanagement system (Gelcich et al. 2006, Schumann 2010), this is the first time that linking and bridging types are empirically studied and correlated with performance. Our findings suggest the importance of factoring social capital in future adaptation and refinements of the policy. Governance is about setting the rules that are binding for a set of actors, and the state has, by means of policy making, privileged capacities to shape comanagement networks (Carlsson and Sandström 2008). If social capital and networks are concurrent factors of good and bad performance, then comanagement regulations and instruments should include vertical and horizontal relationship enhancing mechanisms. For instance, multistakeholder midscale coordination platforms (San Martín et al. 2010) and partnership requirements for funding allocation (Schneider et al. 2003) can stimulate more stable relationships, trust building, and collaboration among actors at various levels. A social network approach to social capital provides critical insights to build new forms of cooperative governance of coastal marine commons in Chile and elsewhere.

Responses to this article can be read online at: http://www.ecologyandsociety.org/vol17/iss 1/art13/ responses/

\section{Acknowledgments:}

The authors thank the small-scale fisher organizations that participated in the study and particularly honor those impacted by the 2010 tsunami in the Bio-Bio region. This paper is dedicated to them in hopes of recovery. We also thank SERNAPESCA professionals in Quintero, Valparaíso, Tomé, Talcahuano, and Coronel who kindly accepted to be interviewed and to respond our questionnaire. The research was supported by Fondap-Fondecyt 1501-0001 (grant to S. Navarrete and J.C. Castilla), Fondecyt 11070034, LINCGlobal (grant to C. Duarte and S. Gelcich), and the Canada Research Chair in Community-Based Resource Management (F. Berkes).

\section{LITERATURE CITED}

Adler, P. S., and S. Kwon. 2002. Social capital: prospects for a new concept. Academy of Management Review 27(1):17-40.

Ballet, J., N. Sirven, and M. Requiers-Desjardins. 2007. Social capital and natural resource management: a critical perspective. Journal of Environment Development 16:355-374. http://dx.doi.org/10.1177/1070496507310740

Berkes, F. 2006. From community-based resource management to complex systems. Ecology and Society 11(1): 45. [online] URL: http://www.ecologyandsociety.org/vol11/iss1/ $\underline{\operatorname{art} 45 /}$

Berkes, F. 2007. Adaptive co-management and complexity: exploring the many faces of comanagement. Pages 19-37 in 
D. Armitage, F. Berkes, and N. Doubleday, editors. Adaptive co-management: collaboration, learning, and multi-level governance. University of British Columbia Press, Vancouver, British Columbia, Canada.

Berkes, F. 2009. Evolution of co-management: role of knowledge, bridging organizations and social learning. Journal of Environmental Management 90:1692-1702. http:// dx.doi.org/10.1016/j.jenvman.2008.12.001

Bernal, P., D. Oliva, B. Aliaga, and C. Morales. 1999. New regulations in Chilean fisheries and aquaculture: ITQ's and territorial user rights. Ocean \& Coastal Management 42:119-142. http://dx.doi.org/10.1016/S0964-5691(98)00049-0

Bodin, Ö., B. Crona, and H. Ernstson. 2006. Social networks in natural resource management: what is there to learn from a structural perspective? Ecology and Society 11(2): r2. [online] URL: http://www.ecologyandsociety.org/vol11/iss2/resp2/

Bodin, Ö., and B. I. Crona. 2008. Management of natural resources at the community level: exploring the role of social capital and leadership in a rural fishing community. World Development 36(12):2763-2779. http://dx.doi.org/10.1016/j.w orlddev.2007.12.002

Bodin, Ö., and B. I. Crona. 2009. The role of social networks in natural resource governance: what relational patterns make a difference? Global Environmental Change 19:366-374. htt p://dx.doi.org/10.1016/j.gloenvcha.2009.05.002

Borgatti, S. P., and M. G. Everett. 1997. Network analysis of 2-mode data. Social Networks 19:243-269. http://dx.doi.org/1 $\underline{0.1016 / \mathrm{S} 0378-8733(96) 00301-2}$

Borgatti, S. P., C. Jones, and M. G. Everett. 1998. Network measures of social capital. Connections 21(2):27-36.

Borrini-Feyerabend, G., M. Pimbert, M. T. Farvar, A. Kothari, and Y. Renard. 2004. Sharing power. Learning by doing in comanagement of natural resources throughout the world. International Institute for Environment and Development and International Union for Conservation of Nature/Commission on Environmental, Economic and Social Policy/Collaborative Management Working Group, Cenesta, Tehran, Iran.

Bourdieu, F. 1979. Les trois états du capital culturel. Actes de la recherche en sciences sociales 31:2-3.

Bourdieu, P. 1986. The forms of capital. Pages 241-58 in J. G. Richardson, editor. Handbook of theory and research for the sociology of education. Greenwood, New York, New York, USA.

Carlsson, L., and F. Berkes. 2005. Co-management: concepts and methodological implications. Journal of Environmental Management 75:65-76. http://dx.doi.org/10.1016/j.jenvman.2 $\underline{004.11 .008}$
Carlsson, L. G., and A. C. Sandström. 2008. Network governance of the commons. International Journal of the Commons 2(1):33-54. [online] URL: http://www.thecommon sjournal.org/index.php/ijc/article/view/20

Cash, D. W., W. Adger, F. Berkes, P. Garden, L. Lebel, P. Olsson, L. Pritchard, and O. Young. 2006. Scale and crossscale dynamics: governance and information in a multilevel world. Ecology and Society 11(2): 8. [online] URL: http://ww w.ecologyandsociety.org/vol11/iss2/art8/

Castilla, J. C. 1994. The Chilean small scale benthic shellfisheries and the institutionalization of new management practices. Ecological International Bulletin 21:47-63.

Castilla, J. C. 2010. Fisheries in Chile: small pelagics, management, rights, and sea zoning. Bulletin of Marine Science 86(2):221-234.

Castilla, J. C., and M. Fernandez. 1998. Small-scale benthic fisheries in Chile: on co-management and sustainable use of benthic invertebrates. Ecological Applications 8(1):S124S132. http://dx.doi.org/10.2307/2641370

Castilla, J. C., P. Manríquez, J. Alvarado, A. Rosson, C. Pino, C. Espóz, R. Soto, D. Oliva, and O. Defeo. 1998. Artisanal "caletas": as units of production and co-managers of benthic invertebrates in Chile. Canadian Journal of Fisheries and Aquatic Sciences 125:407-413.

Coleman, J. S. 1988. Social capital in the creation of human capital. American Journal of Sociology 94:S95-S121. http://d x.doi.org/10.1086/228943

Faust, K. 1997. Centrality in affiliation networks. Social Networks 19:157-191. http://dx.doi.org/10.1016/S0378-8733 (96)00300-0

Gelcich, S., G. Edwards-Jones, and M. J. Kaiser. 2007. Heterogeneity in fishers' harvesting decisions under a marine territorial user rights policy. Ecological Economics 61:246-254. http://dx.doi.org/10.1016/j.ecolecon.2006.02.017

Gelcich, S., G. Edwards-Jones, M. J. Kaiser, and J. C. Castilla. 2006. Co-management policy can reduce resilience in traditionally managed marine ecosystems. Ecosystems 9:951-966. http://dx.doi.org/10.1007/s10021-005-0007-8

Gelcich, S., G. Edwards-Jones, M. J. Kaiser, and E. Watson. 2005. Using discourses for policy evaluation: the case of marine common property rights in Chile. Society \& Natural Resources 18:377-391. http://dx.doi.org/10.1080/0894192059 $\underline{0915279}$

Gelcich, S., N. Godoy, and J. C. Castilla. 2009. Artisanal fishers' perceptions regarding coastal co-management policies in Chile and their potentials to scale-up marine biodiversity conservation. Ocean \& Coastal Management 52 (8):424-432. 
Gelcich, S., T. P. Hughes, P. Olsson, C. Folke, O. Defeo, M. Fernandez, S. Foale, L. H. Gunderson, C. Rodríguez-Sickert, M. Scheffer, R. S. Steneck, and J. C. Castilla. 2010. Navigating transformations in governance of Chilean marine coastal resources. PNAS 107(39):16794-16799. http://dx.doi.org/10.1 $\underline{073 / \text { pnas. } 1012021107}$

González, J., W. Stotz, J. Garrido, J. M. Orezanz, A. Parma, C. Tapia, and A. Zuleta. 2006. The Chilean TURF system: how is it performing in the case of the Loco fishery? Bulletin of Marine Science 73(3):499-527.

Grafton, R. Q. 2005. Social capital and fisheries governance. Ocean \& Coastal Management 48:753-766. http://dx.doi.org $\underline{\text { 10.1016/j.ocecoaman.2005.08.003 }}$

Gutiérrez, N. L., R. Hilborn, and O. Defeo. 2011. Leadership, social capital and incentives promote successful fisheries. Nature 470:386-389. http://dx.doi.org/10.1038/nature09689

Hanneman, R. A., and M. Riddle. 2005. Introduction to social network methods. University of California, Riverside, California, USA. [online] URL: http://faculty.ucr.edu/ hanne $\underline{\text { man/ }}$

Krishna, A. 2002. Active social capital. Columbia University Press, New York, New York, USA.

Krishna, A., and N. Uphoff. 1999. Mapping and measuring social capital: a conceptual and empirical study of collective action for conserving and developing watersheds in Rajasthan, India. Social Capital Initiative Working Paper No. 13. World Bank, Washington, D. C., USA.

Lakon, C. M., D. C. Godette, and J. R. Hipp. 2008. Networkbased approaches for measuring social capital. Pages 63-81 in I. Kawachi, S. V. Subramanian, and D. Kim, editors. Social capital and health. Springer, New York, New York, USA. http://dx.doi.org/10.1007/978-0-387-71311-3_4

Lin, N. 1999. Building a network theory of social capital. Connections 22(1):28-51.

Lin, N. 2000. Inequality in social capital. Contemporary Sociology 29(6):785-795. http://dx.doi.org/10.2307/2654086

Lin, N. 2001. Social capital: a theory of social structure and action. Cambridge University Press, Cambridge, UK.

Marín, A., and F. Berkes. 2010. Network approach for understanding small-scale fisheries governance: the case of the Chilean coastal co-management system. Marine Policy 34:851-858. http://dx.doi.org/10.1016/j.marpol.2010.01.007

Marsden, P. V. 2002. Egocentric and sociocentric measures of network centrality. Social Networks 24:407-422. http://dx. doi.org/10.1016/S0378-8733(02)00016-3
Moerbeek, H., and A. Need. 2003. Enemies at work: can they hinder your career? Social Networks 25:67-82.

Newman, L. L., and A. Dale. 2005. Network structure, diversity, and proactive resilience building: a response to Tompkins and Adger. Ecology and Society 10(1): r2. [online] URL: http://www.ecologyandsociety.org/vol10/iss1/resp2/

Organization for Economic Cooperation and Development (OECD). 2001. The wellbeing of nations: the role of human and social capital. Centre for Educational Research and Innovation, OECD, Paris, France.

Portes, A. 1998. Social capital: its origins and applications in modern sociology. Annual Review of Sociology 24:1-24. http ://dx.doi.org/10.1146/annurev.soc.24.1.1

Portes, A., and P. Landolt. 2000. Social capital: promise and pitfalls of its role in development. Journal of Latin American Studies 32(2):529-547. http://dx.doi.org/10.1017/S0022216X $\underline{00005836}$

Pretty, J. 2003. Social capital and the collective management of resources. Science 302:1912-1914. http://dx.doi.org/10.1126/ $\underline{\text { science. } 1090847}$

Pretty, J., and H. Ward. 2001. Social capital and the environment. World Development 29(2):209-227. http://dx.do i.org/10.1016/S0305-750X(00)00098-X

Putnam, R. 2000. Bowling alone - the collapse and revival of American community. Simon \& Schuster, New York, New York, USA.

Putnam, R. 2001. Social capital: measurement and consequences. Isuma: Canadian Journal of Policy Research Spring 2001:41-51.

San Martín, G., A. M. Parma, and J. M. L. Orensanz. 2010. The Chilean experience with territorial use rights in fisheries. Pages 1-22 in R. Q. Grafton, D. Squires, M. Tait, and M. Williams, editors. Handbook of Marine Fisheries Conservation and Management. Oxford University Press, New York, New York, USA.

Schneider, M., J. Scholz, M. Lubell, D. Mindruta, and M. Edwardsen. 2003. Building consensual institutions: networks and the National Estuary Program. American Journal of Political Science 47(1):143-158. http://dx.doi.org/10.1111/15 $\underline{40-5907.00010}$

Schumann, S. 2007. Co-management and "consciousness": fishers' assimilation of management principles in Chile. Marine Policy 31:101-111. http://dx.doi.org/10.1016/j.marpo $\underline{1.2006 .05 .008}$

Schumann, S. 2010. A tenuous triumvirate: the role of independent biologists in Chile's co-management regime for shellfish. Marine Policy 34(1):133-138. http://dx.doi.org/10.1 016/j.marpol.2009.05.004 
Subsecretaría de Pesca (SUBPESCA). 2004. Informe Técnico. Análisis del desempeño económico, de las áreas de manejo 2000-2002. Departamento de Análisis Sectorial, Valparaíso, Chile.

Subsecretaría de Pesca (SUBPESCA). 2010. Resumen de estado nacional de las áreas de manejo. Unidad de Recursos Bentónicos, Valparaíso, Chile. [online] URL: http://www.sub pesca.cl/controls/neochannels/neo ch847/neochn847.aspx?appinstance $\mathrm{id}=855 \&$ pubid $=1662$

Szreter, S., and M. Woolcock. 2004. Health by association? Social capital, social theory, and the political economy of public health. International Journal of Epidemiology 33:650-667. http://dx.doi.org/10.1093/ije/dyh013

Thiel, M., E. C. Macaya, E. Acuña, W. E. Arntz, H. Bastias, K. Brokordt, P. A. Camus, J. C. Castilla, L. R. Castro, M. Cortés, C. P. Dumont, R. Escribano, M. Fernandez, J. A. Gajardo, C. F. Gaymer, I. Gomez, A. E. González, H. E. González, P. A. Haye, J. E. Illanes, J. L. Iriarte, D. A. Lancellotti, G. Luna-Jorquera, C. Luxoro, P. H. Manriquez, V. Marín, P. Muñoz, S. A. Navarrete, E. Perez, E. Poulin, J. Sellanes, H. H Sepúlveda, W. Stotz, F. Tala, A. Thomas, C. A. Vargas, J. A. Vasquez, and J. M. Vega. 2007. The Humboldt current system of northern and central Chile: oceanographic processes, ecological interactions and socioeconomic feedback. Oceanography and Marine Biology: An Annual Review 45:195-344.

Van der Gaag, M., and M. Webber. 2008. Measurement of individual social capital. Pages 29-49 in I. Kawachi, S. V. Subramanian, and D. Kim, editors. Social capital and health. Springer, New York, New York, USA.

Woolcock, M. 2001. The place of social capital in understanding social and economic outcomes. Isuma 2 (1):11-17.

Woolcock, M., and D. Narayan. 2000. Social capital: implications for development theory, research, and policy. World Bank Research Observer 15(2):225-249.

Woolcock, M., and A. T. Sweetser. 2002. Bright ideas: social capital—the bonds that connect. ADB Review 34(2):26-27. 


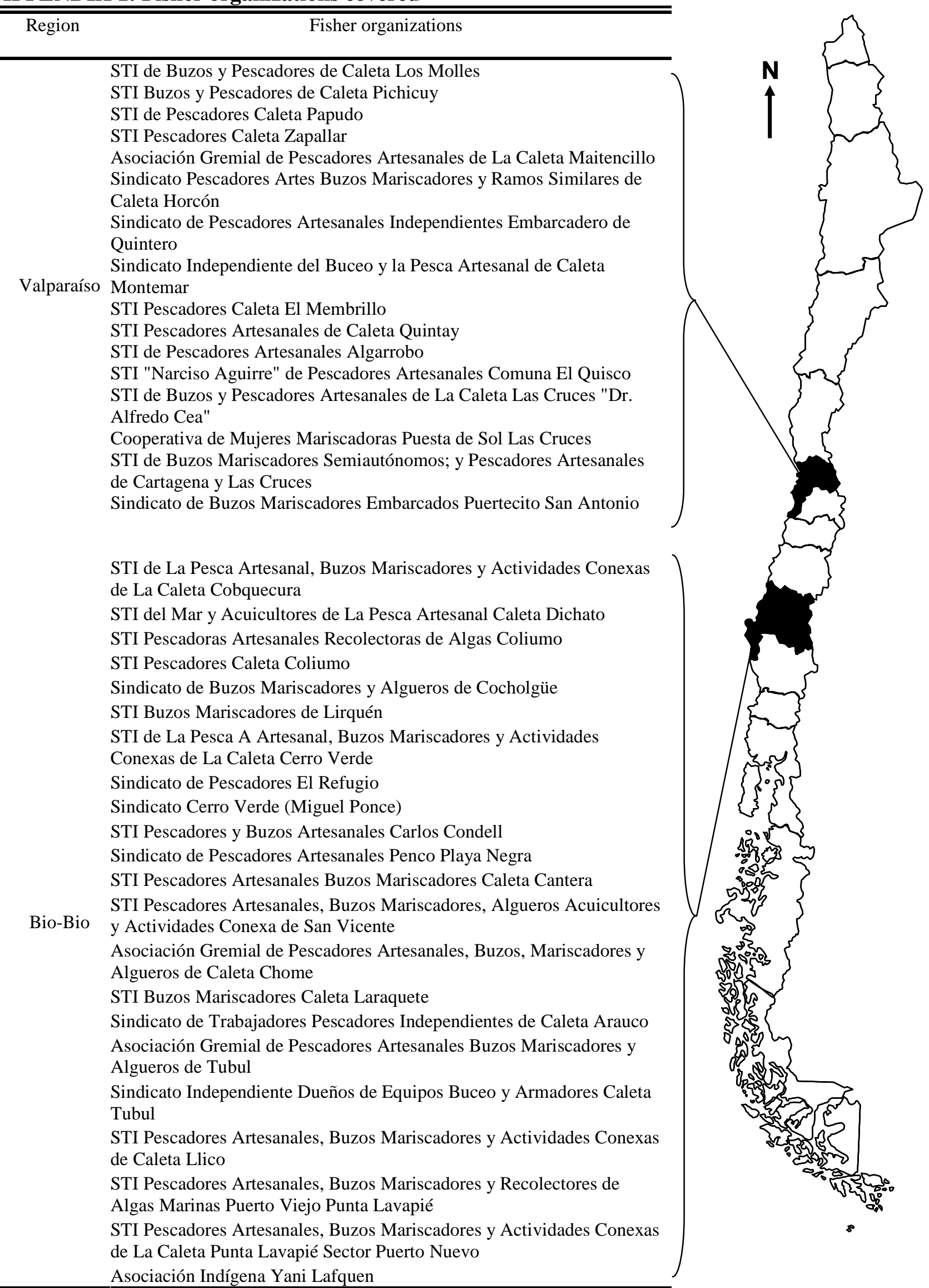


APPENDIX 2: List of actors involved in the Chilean MEABRs system used in the questionnaire

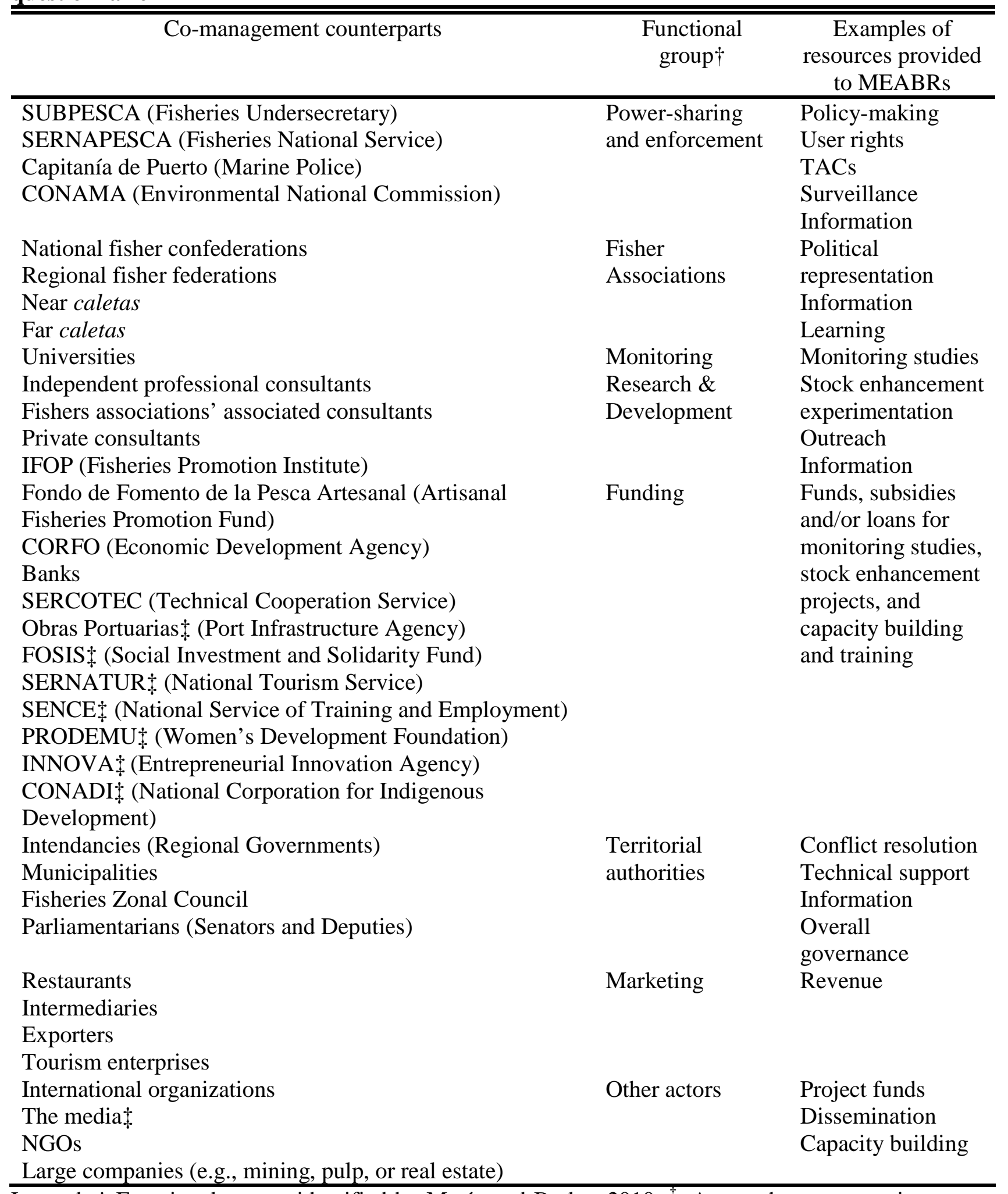

Legend: $\dagger$ Functional groups identified by Marín and Berkes 2010; ${ }^{\ddagger}$ : Actors that were not in the original roster but were added by the informants. 
APPENDIX 3: Features of "star caletas" in the MEABRs co-management system, as reported by multiple informants from the small-scale fishery, public, private and academic sectors.

\begin{tabular}{|c|c|c|}
\hline Region & Fisher orgs. & Features \\
\hline \multirow[t]{14}{*}{ Valparaíso } & Los Molles & Stable harvests from MEABRs and good resource stock \\
\hline & & High productivity and organizational stability \\
\hline & & Produce diversification: algae exploitation \\
\hline & & Livelihood diversification (e.g., tourism services) \\
\hline & & Equitable distribution of benefits among members \\
\hline & Papudo & Produce diversification: exploring algae exploitation \\
\hline & & Well organized and laborious group \\
\hline & Maitencillo & Restocking and aquaculture experimentation \\
\hline & & Livelihood diversification (e.g., tourism services) \\
\hline & & Organizational robustness and many projects funded \\
\hline & & Fishers trained and involved in MEABRs monitoring team \\
\hline & Quintay & Aquaculture and experimentation initiatives \\
\hline & & Well organized group and many projects funded \\
\hline & & $\begin{array}{l}\text { National pioneering case: Influence on, and recognition from, } \\
\text { caletas elsewhere }\end{array}$ \\
\hline \multirow[t]{9}{*}{ Bio-Bio } & Dichato & High productivity of their MEABRs \\
\hline & & $\begin{array}{l}\text { Produce diversification: preliminary aquaculture project } \\
\text { (pioneers in partnering with private processing companies) }\end{array}$ \\
\hline & & Livelihood diversification (e.g., tourism services) \\
\hline & & $\begin{array}{l}\text { Well organized and autonomous group with fundraising } \\
\text { capacities }\end{array}$ \\
\hline & Cantera & $\begin{array}{l}\text { Produce diversification: highly productive MEABRs with } \\
\text { multiple target species }\end{array}$ \\
\hline & & Good marketing strategies \\
\hline & Llico & Among the most productive MEABRs \\
\hline & & Livelihood diversification (e.g., tourism services) \\
\hline & & Consolidated in productive, social and cultural terms \\
\hline
\end{tabular}

